\title{
O olhar feminino sobre a dispersão portuguesa no romance $O$ vale da paixão
}

\author{
The feminine eye on the Portuguese dispersion in \\ the novel $O$ vale da paixão
}

FABIO SOARES DA SILVA*

RESUMO: O ROMANCE O VALE DA PAIXÃO, ESCRITO PELA AUTORA PORTUGUESA LÍDIA JORGE, OFERECE-NOS A POSSIBILIDADE DE REFLETIRMOS SOBRE A DIÁSPORA LUSITANA OCORRIDA NA SEGUNDA METADE DO SÉCULO XX. INTEIRAMENTE NARRADO POR UMA PERSONAGEM FEMININA, A OBRA GANHA TONALIDADES ORIGINAIS, POIS MOSTRA-NOS O PROBLEMA DA EMIGRAÇÃO A PARTIR DA PERSPECTIVA DE QUEM PERMANECE EM PORTUGAL. ESTE ARTIGO VISA, ASSIM, ANALISAR A RELAÇÃO QUE OS PERSONAGENS ESTABELECEM COM SEUS ESPAÇOS (NOVOS E ANTIGOS) E, QUANDO POSSÍVEL, ESTABELECER PARALELOS ENTRE A FICÇÃO E OS FATOS HISTÓRICOS DE PORTUGAL.

ABSTRACT: THE NOVEL O VALE DA PAIXÃO, WROTE BY THE POTUGUESE WRITER LIDIA JORGE, GIVES US THE OPPORTUNITY TO REFLECT ON THE PORTUGUESE DIASPORA IN THE SECOND HALF OF THE TWENTIETH CENTURY. FULLY NARRATED BY A FEMALE CHARACTER, THE STORY IS ENRICHED WITH ORIGINAL SHADES, BECAUSE IT REVEALS THE PROBLEM OF MIGRATION FROM THE PERSPECTIVE OF THOSE WHO STAY IN PORTUGAL. THIS ARTICLE AIMS TO ANALYZE THE CHARACTERS' RELATIONSHIP WITH THEIR SPACES (NEW OR OLD) AND, WHEN IT IS POSSIBLE, TO DRAW PARALLELS BETWEEN FICTION AND HISTORICAL FACTS OF PORTUGAL.

PALAVRAS-CHAVE: DIÁSPORA PORTUGUESA, MIGRAÇÃO, ESPAÇO, PORTUGAL. KEYWORDS: PORTUGUESE DIASPORA, MIGRATION, SPACE, PORTUGAL.

* Doutor em literatura na Sorbonne (Paris 4), especializado em literatura infanto-juvenil. Atualmente ensina língua e literatura na Aix-Marseille Université. É autor do livro Sexualité, sexisme, homoparentalité et autres valeurs, pela Presses Académiques Francophones. Pertence ao Centre de Recherches Interdisciplinaires sur les Mondes Ibériques Contemporains (CRIMIC). 


\section{ntrodução}

A imensidão oceânica nunca intimidou o povo português. Há séculos a literatura lusitana testemunha a ousadia daqueles que desbravaram os mares em busca de novos horizontes. A obra quinhentista de Luís Vaz de Camões, Os Lusíadas, ainda hoje é o texto mais emblemático desse anseio português, mas muitos outros autores exploraram a mesma temática através de perspectivas bem diferentes da epopeia camoniana. Para os que se aventuraram mar adentro, deixar a terra natal simbolizava, muitas vezes, o tão desejado "novo começo". No entanto, para os que permaneceram, a "partida" ganha outra acepção, a de "dividir(-se) em partes, fazer(-se) em porções ou pedaços; separar ou ficar separado” (HOUAISS, 2001, p. 1284). Preocupação já expressa, no século XVII, por Manoel Severim de Faria nas Notícias de Portugal, que, buscando entender a grande emigração portuguesa, perguntou-se: "por que falta a gente desse Reino?” (DE FARIA, 1655, p. 05). De forma indireta, o mesmo questionamento prolonga-se e repercute-se, no final do século XX, no romance de Lídia Jorge, O Vale da Paixão.

Através do olhar de uma jovem, a obra conta cerca de cinquenta anos da história da família Dias. O relato inicia-se no final dos anos quarenta e estende-se até meado de oitenta. Durante esse período, a narradora testemunha a fragmentação gradativa da família e a sua dispersão em diferentes países. O leitor descobre as duas realidades relacionadas à diáspora portuguesa: a partida inevitável de entes queridos e a desolação dos que permaneceram no país (uma desolação alimentada por um profundo sentimento de abandono).

Embora não se trate de um romance histórico, a ilusão mimética é alimentada pela menção de acontecimentos históricos tais como o fim da Segunda Grande Guerra, a guerra colonial, o declínio econômico da região do Algarve e o êxodo português durante o regime salazariano. Este último aspecto, porém, subjaz-se na obra unicamente através da metáfora da família Dias.

Por ser uma obra de tom testemunhal, cujo olhar feminino mostra-se onipresente, a compreensão da representação do espaço ficcional oferece-nos uma visão singular sobre quase meio século de diáspora portuguesa. A romancista tange a problemática valorizando a percepção das mulheres que permaneceram no país. Contudo, a dispersão da família não é unicamente masculina. Certos personagens femininos também participaram do esvazia- 
mento gradativo da casa de Valmares (epicentro da trama de Lídia Jorge). Sendo assim, a obra desdobra-se na bifacialidade já mencionada referente à emigração lusitana, isto é, a partida de uns e a permanência de outros. É por essa razão que o estudo atento da relação entre personagem e espaço favorece a reflexão sobre o diálogo que permeia a dimensão fictiva e a realidade histórica portuguesa.

Amplamente explorada em análise literária, a noção de espaço é por vezes problemática por englobar uma infinidade de conceitos bem diversos e controversos. O presente trabalho não pretende assumir uma missão consensual, pois não se busca aqui harmonizar as diferentes polaridades teóricas sobre a questão nem desenvolver uma abordagem aprofundada sobre a mesma. Busca-se, antes de tudo, propor apenas uma leitura possível sobre a relação que os personagens femininos estabelecem com seu(s) espaço(s). Subentende-se, logo, que muitas abordagens possíveis são deixadas de lado, já que o assunto é demasiadamente complexo para ser explorado em somente algumas linhas. Essa limitação não nos impossibilita realizar uma análise acertada e uma reflexão pertinente sobre as relações estabelecidas entre a mulher portuguesa e a espacialidade romanesca na obra $O$ Vale da Paixão.

Em um primeiro momento, respeitando a bifacialidade referente à diáspora, o ensaio se focalizará essencialmente no estudo de dois personagens (femininos), que testemunham a dispersão da família. Em seguida, procuraremos compreender como a obra representa as mulheres que partiram e a relação que elas estabelecem com a espacialidade original. Vale ressaltar que, ainda que não nos interessemos diretamente em identificar ou listar cronótopos, a noção bakhtiniana (Bakhtine, 1978, p. 238) aqui está embutida, pois tempo e espaço são dimensões indissolúveis e importantes para a compreensão do presente exercício.

\section{O papel da mulher na dispersão portuguesa}

Lídia Jorge apresenta dois personagens femininos bastante fortes em seu romance: a filha de Walter e Maria Ema. Antes de analisar a importância desses personagens, é necessário contextualizá-los na obra, ainda que de maneira breve, pois outros personagens são igualmente importantes e estabelecem, 
com os primeiros, uma relação social complexa. A trama desenrola-se em uma propriedade rural portuguesa chamada São Sebastião de Valmares. As terras pertencem ao viúvo Francisco Dias, homem autoritário que governa uma família bastante numerosa. Custódio Dias, seu filho mais velho, é também seu braço direito. Quando o caçula, Walter, engravida Maria Ema e parte à guerra para evitar os laços matrimoniais, Francisco Dias confere a Custódio a responsabilidade de casar-se com Maria Ema. De uma maneira geral, o romance gira em torno da expectativa de um eventual retorno de Walter a Valmares. Este, porém, prefere aventurar-se pelo mundo, vivendo livremente um modo de vida irresponsável.

Ainda que as expectativas da família de verem Walter Dias novamente fossem grandes, as frustrações de Maria Ema e de sua filha ganham ênfase. A primeira viu-se obrigada a casar-se com um homem que não amava, devendo abafar sua paixão por Walter; a segunda enfrenta o tormento de sentir-se uma filha indesejada. Ela seria a materialização do infortúnio, fruto de um erro, responsável pela infelicidade da família Dias. Tais problemas fazem com que as personagens estabeleçam uma relação conflituosa com seu espaço, pois sentem-se obrigadas a ocultar seus sentimentos em nome de uma harmonia social que não lhes convém ${ }^{1}$.

Existe, de fato, um grande desconforto das personagens com o seu lugar de origem. Ambas parecem enclausuradas em Valmares, incapacitadas de controlarem sua própria vida. Devendo aceitar, sem questionar, as decisões masculinas, notadamente as do patriarca. Aliás, o modelo masculino, dominante, impõe-se em praticamente toda a obra, indicando-nos uma característica do perfil socio-psicológico dessas personagens: a dependência do homem.

A ficção é inteiramente coerente com a realidade de muitas mulheres pertencentes a comunidades rurais portuguesas, no período retratado. Esse aspecto percorre muitas obras de Lídia Jorge, como $O$ dia dos prodígios ou $O$ cais das merendas, que revelam, através da perspectiva feminina, facetas históricas e políticas de comunidades agrárias do sul de Portugal (FORNOS, 2009, p. 60). $\mathrm{O}$ romance $O$ vale da paixão assinala um fator importante referente à partici-

\footnotetext{
${ }^{1}$ Cf. Ferreira, Ana Paula. Para um leitor ignorado: ensaios sobre a ficção de Lídia Jorge. 1 edição. Lisboa: Alfragide, 2009. A autora reúne vários estudos que estabelecem reflexões sobre diferentes aspectos da ficção de Lídia Jorge.
} 
pação da mulher no processo de emigração: a decisão de partir era, predominantemente, masculina. A mulher que não acompanhasse o marido (ou que não pudesse segui-lo) ficaria para trás. Na obra de Lídia Jorge, isso fica claro quando a narradora relata a partida de seus tios:

(...) Ao contrário dos outros camponeses que faziam da partida alguma coisa que se assemelhava a uma festa com seu laivo de funeral e de fanfarra, os Dias saíam sem rumor, sem avisar. Separavam-se das alfaias, dos animais, dos estrumes, das lavras, das mulheres, dos filhos e dos grandes quartos, sem ruído, como se fossem fazer compras de comboio e voltassem no dia seguinte. Prometiam ir e voltar num curto espaço. Eles não explicavam a Francisco Dias para onde partiam. Eles mentiam. Lembrava-se. Herdara a imagem da sonsidão pura. Os Dias libertavam-se do pai como coelhos. Silenciosos e rápidos como as lebres nos sonhos. Libertavam-se. (JORGE, 1998, p. 86-87)

O texto informa-nos claramente que a partida dos Dias é, em um primeiro momento, puramente masculina. Ainda assim, a casa de Valmares nunca chega a ser um lar feminino, pois Francisco Dias é um personagem suficientemente imponente para calar as vozes restantes. A maioria dos personagens esconde-se em silêncios, tal como a narradora, que pouco interage com a família. Ela prefere observar tudo calada, relatar os acontecimentos como uma testemunha ocular. Contudo, diferentemente dos demais membros da família, seu silêncio não é de submissão ou de medo do velho patriarca. Ela cala-se, pois assim é sua natureza, porque seus conflitos internos a corroem. Isso faz dela uma pessoa atenta, uma observadora discreta, de olhar crítico sobre tudo e sobre todos.

Ao comparar, ironicamente, seus tios a coelhos ou lebres, a filha de Walter indica a relação de tensão familiar na casa. Não há afrontamentos ou qualquer outra forma explícita de desacordo. Os personagens vivem coagidos como presas, obedecendo as suas exigências e precisando mentir para não o contrariar. Difícil não estabelecer paralelos entre o ambiente familiar do romance e a realidade histórica portuguesa da época. A imagem de um líder solitário e autoritário é demasiadamente próxima do próprio imaginário lusitano vinculado ao ditador António de Oliveira Salazar. Este, ao tomar o poder, aumentou progressivamente as estruturas fiscalizadoras das fronteiras, e isolou Portugal (MADROÑERO, 1987, p. 367). Apesar disso, Salazar nunca declarou, abertamente, ser contra a emigração, já que ela "era encarada como 
uma forma de diminuir o desemprego e de obter divisas por via das remessas dos emigrantes" (STAHL et al, 1982, p.14). Notamos a mesma ambivalência no comportamento de Francisco Dias que, de um lado, incomoda-se com a partida dos filhos e, de outro lado, deseja usufruir das riquezas que conquistariam no estrangeiro (JORGE, 1998, p. 94).

\section{As razões para a partida}

Em Valmares, todos vivem sob o duro julgo do trabalho agrário precário que os impossibilita de sonhar, in loco, com riquezas. A opção é, como indica a passagem, libertar-se do local castrativo, mesmo que isso signifique partir em lugares desconhecidos. Estabelece-se, mais uma vez, um diálogo entre a ficção e a realidade. A esse respeito, António Barreto explica que, para evitar as dificuldades socio-econômicas da época, muitos portugueses "elegeram, como cenário, o mundo, fora de portas” (BARRETO, 1995, p. 842).

O emprego do verbo "libertar-se", para explicar a ação dos tios, deixa subentendido a ideia de uma partida sem regresso. Valmares seria um tipo de prisão ou, simplesmente, um daqueles lugares estéreis que oferecem poucas chances a seus habitantes de obterem realizações pessoais. Em um primeiro momento, o texto não diz que o desejo de fuga foi motivado pela dureza do patriarca, mas, sobretudo, pela dureza do trabalho rural. No trecho anterior, a narradora explica que seus tios deixaram para trás animais, estrume e pertences sem importância. A separação de suas mulheres e filhos, porém, não é duradoura. Poucas linhas depois do anúncio de partida, a narradora detalha a aventura dos tios:

Via-os libertarem-se silenciosos, combinados, soltando gritos temerários por cima do mar. Primeiro Fernandes e Joaquim, em cinquenta e três, depois Manuel e Luís, em cinquenta e quatro, João em cinquenta e seis, Inácio em cinquenta e sete. Afastando-se, desaparecendo, sumindo-se maravilhosamente ao longe, afundando-se em trabalhos estranhos e árduos, confundindo uns com os outros, mandando ir de seguida as mulheres e os filhos, para não voltarem, para serem mais ferozes e mais duros com Francisco Dias, para ultrapassar os atos de Walter. (JORGE, 1998, p. 87)

Neste trecho, a emigração possui um certo tom vingativo, ou seja, o que 
teria incentivado a partida dos filhos seria, justamente, o patriarca. O trabalho que executavam em Portugal, por mais árduo que fosse, não é o problema que os empurrava para fora do país, já que nas terras estrangeiras o labor era igualmente difícil. Sendo assim, o que alimenta o anseio de partir seria, então, a falta de vínculos afetivos com Francisco Dias. Os descendentes partiam para não mais voltar, depois pediam para o resto da família juntar-se a eles. Se fizermos, mais uma vez, um paralelo entre a ficção e a realidade social e histórica portuguesa, a obra abre-nos para duas questões: primeiramente, a passagem confirma o fato que a emigração é um fenômeno inicialmente masculino. As mulheres (e filhos pequenos) se juntariam aos maridos posteriormente. A esse respeito, o historiador José Mattoso chama o fenômeno de "sobremasculinidade da emigração" (MATTOSO, 1998, p. 375); segundo, a emigração não tem como motivação única o problema econômico. A partida também pode estar relacionada a desilusões políticas. A ditadura representa um endurecimento social podendo alimentar o sentimento de viver sob o governo de um Estado injusto. Vinculado a essa ideia está o medo de agressões à integridade física e/ou intelectual. Por mais que o líder exalte os valores nacionais, seu poder vive da usurpação da democracia. Subentende-se, nessa filosofia, a aniquilação de todo pensamento contrário à política dominante. $\mathrm{Na}$ ficção de Lídia Jorge, o comportamento autoritário de Francisco Dias assemelha-se ao de um ditador, pois tende a menosprezar os anseios alheios para priorizar os seus desejos.

No trecho acima citado, a filha de Walter especifica o ano de partida de cada um de seus tios. Todos partiram durante a década de cinquenta. Mais uma vez, é curioso notar a ligação entre a ficção e a realidade, pois foi justamente nas décadas de cinquenta a sessenta que Portugal conheceu um enorme fluxo emigratório (MATTOSO, 1998, p. 374). Isso demonstra que houve uma preocupação, da parte da autora, de alimentar a ilusão mimética ao propor datas que fossem coerentes com a realidade histórica do país. Todavia, é difícil afirmar que haja, da parte da autora, a intenção consciente de criar uma narrativa metaforizando os acontecimentos históricos portugueses relacionados à emigração.

Independente do fato de ser uma escolha consciente ou não, o problema da emigração é um ponto crucial e quase inevitável na obra. O que realmente afeta a narradora é a ausência do pai e o impacto destrutivo que sua partida 
desferiu nos demais. Porém, a medida em que outras partidas são anunciadas, o que era um ato isolado e inconsequente transforma-se em fatalidade coletiva. Um a um, os irmãos de Walter Dias seguem seu exemplo "irresponsável” e deixam para trás a vida penosa e infrutífera de São Sebastião de Valmares.

\section{O sentimento de abandono}

Como pudemos observar no trecho anterior, o livro não apresenta o esvaziamento da casa aos poucos, ao longo da obra. Em apenas um parágrafo inteiramo-nos da dispersão dos membros da família. Vale salientar que o anúncio não é tão pontual e súbito. A informação repete-se várias vezes e em diferentes momentos da história. $\mathrm{Na}$ realidade, já na primeira página do romance a narradora encontra-se em uma casa quase vazia. Seu discurso nostálgico apresenta-se da seguinte maneira:

Nessa altura, a casa de Valmares já havia perdido a maior parte dos seus habitantes, e os compartimentos onde tinham vivido os descendentes de Francisco Dias encontravam-se fechados, ao longo do corredor por onde antigamente todos cruzavam. Então era muito difícil distingui-los pelas passadas. Vários filhos e vários netos, três noras e um genro, caminhando sem cessar desde madrugada, forneciam uma multitude de ruídos indestrinçáveis para quem fosse menor e ficasse à escuta, horas a fio, dentro dum quarto. Porém, naquele Inverno, no início dos anos sessenta, os passos dos que restavam eram tão identificadores quanto as suas caras e seus retratos. (JORGE, 1998, p. 09)

De imediato, chama-nos a atenção a comparação implícita entre o passado e o presente da narrativa. Os elementos descritivos são poucos, mostrando-nos que não existe a preocupação de acrescentar informações puramente “decorativas". O termo, utilizado por Vitor Manuel de Aguiar e Silva, refere-se aos narradores que se comprazem "[...] na descrição morosa e minudente de um personagem, de um objecto, de uma paisagem, exibindo a opulência do seu léxico [...]". (AGUIAR E SILVA, 1982, p. 709). Este aspecto, porém, não se manifesta na obra de Lídia Jorge, pois a casa, em si, é pouco descrita. O que se deseja acentuar é o contraste entre o vazio (do "agora") e o cheio (do "antes"), isto é, de como ela era povoada durante uma época anterior aos anos sessenta e como, posteriormente, ela tornou-se em um lugar quase 
abandonado. A própria descrição busca “esvaziar" o lar, despindo os cômodos de móveis e de outros detalhes que, eventualmente, possam enriquecê-lo, tornando-o um lugar convivial. Os lugares e seus elementos correlatos materializam-se a medida em que a narradora impregna-os com a alma dos habitantes que não vivem mais lá. Tal efeito acaba por acentuar ainda mais a impressão de visualizarmos uma casa abandonada, habitada apenas pelas recordações nostálgicas da narradora.

Para referir-se a um espaço enriquecido de novas conotações, Osman Lins fala de atmosfera (LINS, 1976, p. 76). Esta "manifestação do espaço" surge de sua relação com o personagem. No caso do O Vale da Paixão, além da maneira econômica de descrever a casa, outros elementos textuais contribuem na criação de sua atmosfera de abandono. Se observarmos atentamente o campo lexical, nota-se que a narradora enfatiza a sua impossibilidade de reviver momentos passados. A utilização de palavras como "perdido" (em "perdido a maior parte de seus habitantes") e "fechados" (em "encontravam-se fechados") ressalta a ideia de solidão, abandono, de passado resoluto. Mesmo o substantivo "Inverno", associado inexoravelmente ao frio, conota a ideia de isolamento, de estagnação, um período infrutífero ou de baixa produtividade natural. No caso do romance, a menção do inverno não deixa de ser coerente, já que a personagem encontra-se em um período monótono e estéril de sua vida.

A grande quantidade de pessoas que viviam naquele lugar é acentuada através da memória auditiva da narradora, reforçando a imaterialidade corpórea dos antigos habitantes. Este fator enfatiza ainda mais a esterilidade dos compartimentos inabitados. Logo, os "vários ruídos" de outrora, que animavam a casa, são como fantasmas a assombrar um presente moroso e vazio de acontecimentos. No final da passagem, a narradora ressalta que alguns membros permaneceram na casa, mas nada é como na época em que os ruídos se misturavam de maneira caótica. O fato de afirmar que os passos, a cara e os retratos (dos que permaneceram) repetem-se em demasia salienta ainda mais o enfado da narradora.

O sentimento de abandono faz surgir nos personagens o desejo que seus familiares regressem. Depois das primeiras partidas, a esperança parece um sentimento latente em toda a obra. A todo momento existe a ansiedade do regresso: para Maria Ema, a volta do amante; para a narradora, o regresso do 
pai; para Francisco Dias, a volta dos filhos enriquecidos. Assim, misturado ao sentimento de abandono encontrava-se também a esperança. $\mathrm{O}$ velho patriarca também manifestava sua ansiedade pedindo a seu filho Custódio para que deixasse o portão da casa encostado, pois estava convícto que seus outros filhos já estavam por chegar (JORGE, 1998, p. 169).

Até que chega o momento em que tomam consciência de que ninguém voltaria. A decepção exprime-se por meio de gestos, de comportamentos compulsivos. Maria Ema deprime-se quando finalmente entende que Walter Dias não regressaria mais. A sua filha, no afã de suprir sua falta da figura masculina, adquire uma conduta claramente autodestrutiva, multiplicando seus parceiros sexuais (sempre homens desconhecidos, mais velhos, bêbados e ignorantes) (JORGE, 1998, p. 166). Dessa forma, a narradora reabilita a figura do pai para destruí-la e libertar-se (BESSE, 2013, p. 124). Para ela, até mesmo a ausência dos parentes torna-a antipática à ideia de revê-los, a ponto de não desejar que voltem à São Sebastião de Valmares "nem iguais nem mudados" (JORGE, 1998, p. 174). A única lembrança que ela desejava preservar é a imagem de seus tios, ainda pobres, sem as realizações profissionais que os enriqueceram posteriormente.

De uma certa maneira, a distância é muitas vezes sentida como uma traição. Como se os filhos do patriarca fossem ingratos ou vingativos. O trecho a seguir ilustra tal sentimento:

(...) Afinal ele (Custódio) aumentava a família com novos netos, no momento em que outros filhos e os outros netos partiam com destino ao Canadá, Estados Unidos, América do Sul. Como se estivessem empenhados em separar-se pelo mundo a fora, como se quisessem construir o inverso dos estados unidos de Francisco Dias. Era como se a mesa familiar, ano após ano, se estilhaçasse e cada uma das partes fosse ter a uma região do mundo. (JORGE, 1998, p. 90)

Mais uma vez a obra permite-nos estabelecer uma reflexão sobre a diáspora portuguesa. De acordo com o historiador José Mattoso, entre 1946 e 1973 quase dois milhões de pessoas deixam Portugal (JORGE, 1998, p. 374). O número é bastante alarmante quando sabemos que Portugal não possui nem mesmo nove milhões de habitantes nessa mesma época. Somado a essa ideia acrescenta-se o fato que a população jovem, ativa, responsável pelo crescimento do país, é a primeira a deixar suas terras. As possíveis consequências 
desse fluxo são observáveis no livro quando analisamos o perfil das pessoas que permaneceram em São Sebastião de Valmares: duas mulheres, um idoso e um deficiente físico.

Os três perfis não deixam de ser emblemáticos, pois não representam, $a$ priori, o perfil do emigrante. Todavia, a eles cabe a missão de restaurar o equilíbrio de outrora. Os "estados unidos de Francisco Dias", como ironiza a narradora, (e aqui pode subentender-se também "Portugal de Salazar") encontravam-se destinados ao fracasso, pois por mais que Custódio Dias fizesse novos netos, suas terras já não possuíam mais a mesma quantidade de braços para cultivá-las. Seus maiores inimigos, como sugere a passagem, são os países estrangeiros.

A esse respeito, Portugal dos anos sessenta enfrenta uma série de problemas que desgasta o regime e faz com que uma parcela da população perca o interesse de permanecer no país. Dos vários fatores que provocaram a debandada portuguesa, podemos citar, por exemplo, a política colonialista inflexível de Salazar, que se opunha radicalmente à independência das colônias ultramarinas (LABOURDETTE, 2003, p. 585). Contrariando as resoluções da ONU (MALTEZ, 2004, p. 501), Portugal acaba perdendo o apoio da comunidade internacional, encontrando-se só diante de seus inúmeros problemas sociais (Labourdette, 2003, p. 587).

\section{As mulheres emigrantes}

Sem sombras de dúvida, o romance enfatiza muito mais a dispersão portuguesa a partir da perspectiva dos que permaneceram em Portugal. Fato que explica porque ela é interpretada muitas vezes de maneira tão negativa. A obra menciona igualmente as mulheres que deixaram a casa de Valmares. No entanto, elas possuem pouquíssimo destaque, visto que o texto prefere seguir o modelo machista dominante segundo o qual a mulher exerce somente funções mais triviais. Não se pode exprobrar a decisão da autora de privilegiar o modelo social dominante, mas chama-nos a atenção o sexismo que o texto nos revela. Mesmo Adelina, filha de Francisco Dias, muitas vezes apaga-se na sombra de seu marido Fernandes.

Somente quando a trama aproxima-se do final que as personagens femini- 
nas criam um pouco mais de individualidade. A narradora deixa de chamá-las apenas de "as mulheres" para finalmente nomeá-las. Todavia, elas continuam exercendo um papel relativamente secundário, pois realizam tarefas que os seus maridos não desejam fazer: escrever cartas para falar sobre problemas familiares. Na passagem abaixo, vemos como a filha de Walter apresenta sua tia Vitória:

A primeira é escrita por Vitória, a mulher daquele que tem o limousine-service, Manuel Dias, o que fora mineiro com uma luz especial na aba do chapéu. Sóbria sobre a sua própria família, a mulher de Manuel apenas diz que por vezes, em Otava, escurece cedo de mais, e de resto tudo normal. Os filhos estudam e tocam sax, e Manuel ficou presidente de um clube. Mas ela, naturalmente, escreve por causa de outro assunto. (JORGE, 1998, p. 86-87)

As referências que o leitor recebe da narradora valorizam muito mais Manuel Dias. Ele é um homem com um passado e bens. Vitória é apresentada como "a mulher daquele que tem o limousine-service" ou, simplesmente, "a mulher de Manuel”. Ou seja, ela não tem biografia, é praticamente um tipo de posse de seu marido. Já Adelina Dias, que passa quase todo o romance "escondida" atrás de Fernandes, ganha um pouco mais de importância no final da obra. Contudo, muitos anos depois de instalar-se no Canadá com seu marido, as notícias que ela envia a sua família não é exatamente sobre si, mas sobre seu marido.

No que se refere aos personagens masculinos, a obra conta a evolução de cada um deles. Para aqueles que deixaram São Sebastião de Valmares, os anos de trabalho rude foram recompensados com uma boa situação financeira. Mas as mulheres que seguiram seus maridos não têm uma história própria. O livro não destaca suas vidas de emigrantes nem lhes dá nenhum tipo de mérito. A impressão que podemos ter é de que essas mulheres somente desfrutaram do conforto oferecido por seus maridos.

Embora também não possua uma biografia, Luísa é a única mulher que tem um status diferente. Ela é esposa de Inácio Dias, mas também é sua sócia na construtora em Caracas. Não se trata de mais uma simples dona de casa, como é o caso das outras esposas que escrevem a seus parentes de Valmares. Mesmo assim, cabe a ela escrever para a família de seu marido, já que "Inácio não tem tempo para escrever uma carta” (JORGE, 1998, p. 186). Subenten- 
de-se que Luísa teria mais tempo ocioso em comparação a seu marido e que cabia a ela o dever de realizar as tarefas "secundárias".

Uma outra particularidade dessa personagem é sua maneira de redigir as cartas. Ela mistura a língua portuguesa e a espanhola com grande desenvoltura a ponto de deixar-nos em dúvida sobre sua nacionalidade. Porém, a obra dá pistas discretas que assinalam a proveniência portuguesa da personagem. Este aspecto merece ser destacado, pois o problema está diretamente ligado à questão do emigrante e de sua identidade cultural. Observemos a passagem a seguir:

En la comunidad, fala-se que veio desde o paralelo cinquenta a deitar mujeres sobre a manta e a abandonar os filhos que faz sobre ella. Diz-se en la comunidad. Escrevemos hoje ao pai, para que Custódio lhe escreva, pedindo que volte para aí, pois aqui está envergonhando o nosso apelido e o nome de Portugal. Esta gente de cá es muy patriota. E por isso, Inácio me disse que desta carta devo fazer seis cópias para mandar a cada um dos irmãos. Saludos y recuerdos. Luisa e Inácio Dias, La Constructora Ideal, Caracas. (JORGE, 1998, p. 186)

Luísa Dias tem uma óbvia dificuldade em discernir a diferença entre as duas línguas. É como se o idioma do país de adoção estivesse, aos poucos, apoderando-se da língua materna. O fenômeno linguístico é bastante comum em comunidades estrangeiras bem integradas no novo país. A prova de sua boa integração manifesta-se na sua preocupação insistente sobre o que dizia "la comunidad" sobre o cunhado (Walter Dias). Isso indica que a personagem não era indiferente aos rumores da população. Em outras palavras, a mistura de idiomas seria a consequência de uma nova identidade cultural, nascida do hibridismo de duas nações.

Por outro lado, a influência cultural venezuelana não chegou a apagar os vínculos patrióticos. Segundo Luísa, o que estaria em jogo não seria apenas a reputação de toda a família Dias, os problemas causados por Walter também poderiam prejudicar a própria imagem de Portugal no estrangeiro. A esposa de Inácio incarna, assim, o papel de embaixadora de seu país, devendo redobrar sua atenção no respeito dos valores locais e transmitir uma imagem límpida de seu país de origem.

Apesar da distância, do tempo longe de Portugal, em muitos momentos a narradora dá indícios de que a universalização da família Dias não se traduz, 
obrigatoriamente, por uma mudança de mentalidade. Bem o contrário, os tios e tias pareciam ainda rondar, à distância, a pequena comunidade rural de São Sebastião de Valmares. Para definir a maneira de pensar daqueles que partiram, a narradora explica:

Era como se os filhos de Francisco Dias se encontrassem reunidos num espaço extraordinário, fora da Terra, na zona onde boiam os satélites, e no entanto, esse espaço fosse São Sebastião de Valmares. Era como se não tivessem saído da primitiva comarca, da velha igreja, do antigo pátio desta casa, revisitando estes espaços, pegada a pegada, árvore a árvore(...). Para eles, oitenta e um era mais antigo do que sessenta e dois, e sessenta e dois era mais encontrava-se mais afastado do que cinquenta e um." (JORGE, 1998, p.199)

O comentário da filha de Walter aparece logo após a chegada de inúmeras cartas, oriundas de diferentes partes do continente americano, todos preocupadas em reavivar antigos problemas. $\mathrm{O}$ fato de habitarem em grandes cidades e obterem conquistas financeiras não alterou em nada a mentalidade retrógrada, pois todos continuam presos ao passado, a seus antigos hábitos e problemas. Por essa razão, criaram um novo espaço que ultrapassou as dimensões topográficas habituais. A “zona onde boiam os satélites”, é um lugar virtual onde os filhos emigrantes de Francisco Dias agruparam seus antigos valores, usando-os como se ainda fossem válidas ou importantes ${ }^{2}$. O "espaço extraordinário", como o nomeia a narradora, seria o que Henri Mitterrand chamaria de território (MITTERRAND, 1987, p. 138), se tal lugar fosse, ao menos, um pouco mais tangível na obra.

A questão, aqui, seria entender a relação que os personagens estabelecem com os espaços sociais do outro, ou melhor, como o território estrangeiro é representado. A noção de território, segundo Mitterrand, não está distante da perspectiva sociológica. A sociedade dá ao indivíduo certos direitos sobre um ou vários lugares (coletivos ou privados). Para os moradores de Valmares, por exemplo, há uma evolução na maneira de representar o território fora de Portugal. No início do livro, a imensidão do mundo é-lhes apresentada por

$2 \mathrm{O}$ comportamento dos personagens assemelha-se muito à necessidade de certos imigrantes de preservar hábitos e tradições de sua terra natal. Com o passar do tempo, alguns hábitos podem desaparecer ou perder sua importância no país de origem, porém continuam a ser reavivados pelos imigrantes. $\mathrm{O}$ fenômeno pode criar estranhamentos quando um indivíduo entra em contato com um compatriota emigrante e nota que seus hábitos e costumes não são (mais) equiparáveis. 
meio de cartas enviadas por Walter. Por meio de seus desenhos de pássaros da Índia, Angola, Brasil, Panamá, Canadá, e outros, os Dias sonhavam e passaram a arquitetar o projeto de também deixar o país (JORGE, 1998, p. 86). Para o patriarca, a partida dos filhos era sinônimo de riqueza. "Queria que os filhos chegassem ao fim e lhe dissessem, rápido, que já se encontravam milionários" (JORGE, 1998, p. 94). Em outras palavras, a emigração era algo altamente positiva.

No final da obra, porém, os países estrangeiros que antes despertavam tanto fascínio, perdem o encanto, já que é criado um hiato espaciotemporal bastante grande entre os que partiram e os que permaneceram em Valmares. Dessa forma, o território estrangeiro perdeu todo seu interesse, porque os vínculos afetivos não eram mais os mesmos. Assim, da mesma maneira que a terra estrangeira perde interesse para os habitantes de Valmares, para aqueles que a deixaram, o país natal era nada mais que um pedaço de recordações ingratas.

\section{Considerações finais}

O romance O Vale da Paixão, de Lídia Jorge, é de alta relevância no contexto literário contemporâneo português, pois oferece-nos a uma grande variedade de temáticas. Uma delas, como vimos neste artigo, é a representação ficcional da diáspora lusitana durante a segunda metade do século vinte. A sua originalidade fundamenta-se em abordar a emigração portuguesa, não através da perspectiva aventureira de quem deixou o país, mas através da memória de uma pessoa que permaneceu em Portugal. Ainda que se trate de uma obra fictiva, o tom testemunhal, calcado em um ambiente verossímil, ela permite-nos desenvolver reflexões que dialogam com a história portuguesa.

O contexto no qual a obra se ambienta autoriza-nos, por exemplo, a realizar inferências breves sobre o quadro socio-econômico do país. Sobretudo no tocante à ditadura salazariana e as emigrações ocorridas no mesmo período, assinalados no livro. Vale salientar que as considerações feitas sobre os dois temas são apenas sugestões de leituras. Todavia, a urdidura da obra envereda a leitura para uma interpretação inequívoca sobre a ditadura e a diáspora portuguesa. Os elementos históricos que enriquecem e alimentam a ilusão 
mimética despertam, quase que naturalmente, nosso olhar crítico a respeito dos problemas mencionados. Fato que leva Miriam Denise Kelm afirmar que os personagens da obra seriam "referenciais de momentos históricos e posicionamentos que continuam a vazar na representatividade ficcional portuguesa" (KELM, 2012: p.156).

No que diz respeito à emigração, buscamos privilegiar o estudo da relação que as personagens femininas estabelecem com o espaço. Mas não se pôde ignorar o fato que a obra compõe-se também de personagens masculinos importantes. Por essa razão, julgamos essencial não os amputar, sobretudo porque revelam aspectos significativos sobre a relação social entre o homem e a mulher. Esse ponto merece ser mais aprofundado, visto que a disparidade social entre os gêneros é consideravelmente consequente no romance. Encontramos, por exemplo, tal abordagem nos estudos, já mencionados, de Ana Paula Ferreira, J. L. Giovanani Fornos e Maria Graciete Besse, fato que explica porquê referimo-nos ao problema do sexismo sem entrar nos méritos da questão.

Quanto à análise do espaço ficcional, propriamente dita, não nos preocupamos em estudar a topografia da obra. A decisão de não o fazer se justifica na medida em que a narradora não se interessa em descrever lugares. Sua atenção focaliza-se nos fatos e nas suas impressões sobre os mesmos. Isso significa que os lugares não são "mobiliados" (ECO, 1992, p. 212), deixando ao leitor a tarefa de imaginá-los como bem o entender e o agrade. A noção de espaço foi, assim, privilegiado ao termo lugar, pois o primeiro abrange conotações mais simbólicas.

Nossa reflexão sobre a representação do espaço, na obra de Lídia Jorge, somente ganha relevância quando se busca compreender a relação que as personagens estabelecem entre si. Isso significa que a percepção da narradora-personagem sobre a dispersão familiar ganha sentido quando entendemos os conflitos psicológicos que permeiam a trama. Isso propulsiona-nos a refletir sobre o papel da memória, sobre sua subjetividade e, consequentemente, sobre a parcialidade de sua visão do mundo. Esse aspecto do livro não impõe, de forma alguma, limitações de análise. Muito pelo contrário. Ele serve de convite para que descubramos a dispersão portuguesa a partir de um novo ângulo. 


\section{Referências Bibliográficas}

AGUIAR E SILVA, Vítor Manuel. Teoria da Literatura. Coimbra: Livraria Almedina, 1982. BAKHTINE, Mikhail. Esthétique et théorie du roman. Paris: Editions Gallimard, 1978.

BARRETO, António. Portugal na Periferia do Centro: Mudança Social, 1960-1995. Revista Análise Social, Lisboa, Vol. XXX, n. 134, 1995.

BESSE, Maria Graciete. Memória, empoderamento e ética na obra de Lídia Jorge. Revista Abril - Revista do Núcleo de Estudos de Literatura Portuguesa e Africana da UFF, Rio de Janeiro, Vol. 5, n 11, Novembro de 2013.

BURGOS MADROÑERO, Manuel. A fiscalização das fronteiras portuguesas durante a Guerra civil da Espanha. In COSTA PINTO, António et al. O Estado Novo: das origens ao fim da autarcia (1926-1959). Lisboa: Editora Fragmentos, 1987.

DE FARIA, Severim. Notícias de Portugal. Lisboa: Lisboa Occidental, 1740.

ECO, Umberto. Les Limites de l'Interprétation. Paris: Editions Grasset \& Fasquelle, 1992.

FERREIRA, Ana Paula. Para um leitor ignorado: ensaios sobre a ficção de Lidia Jorge. Lisboa: Alfragide, 2009.

FORNOS, José Luís Giovanani. Lídia Jorge: territórios da paixão e da escrita. Revista Avril - Revista do Núcleo de Estudos de Literatura Portuguesa e Africana da UFF, Rio de Janeiro, Vol. 2, n 2, Abril de 2009.

HOUAISS, A. e VILLAR, M.S. Dicionário da Lingua Portuguesa. Rio de Janeiro: Editora Objetiva, 2001.

JORGE, Lídia. O Vale da Paixão. Lisboa: Publicações Dom Quixote, 1998.

KELM, Miriam Denise. A identidade e a história portuguesas: duas constantes revisitadas na obra de Lídia Jorge. Letras, Santa Maria, v. 22, n. 45, p. 147-163, jul./dez., 2012.

LABOURDETTE, Jean-François. História de Portugal. Lisboa: Dom Quixote, 2003.

LINS, Osman. Lima Barreto e o espaço romanesco. São Paulo: Ática, 1976.

MALTEZ, José Adelino. Tradição e Revolução. Lisboa: Tribuna da História, 2004.

OLIVEIRA MARTINS, J. P. Fomento rural e emigração. Lisboa: Guimarães Editores, 1994.

MATTOSOS, José e ROSAS, Fernando. História de Portugal: o Estado Novo (1926-1974).

Lisboa : Editorial Estampa Lda, 1998.

MITTERRAND, Henri. Le regard et le signe. Paris : Puf écriture, 1987.

SANTOS SILVA, Augusto. A mudança em Portugal, nos romances de Lídia Jorge: esboço de interpretação sociológica. Revista da Faculdade de Letras da Universidade do Porto, Vol. XXIV, 2012.

STAHL, H.M., Ferreira do Amaral, J., Moniz, F. et al. Perspectivas da emigração portuguesa para a CEE 1980-1990. Lisboa: Moraes Editores, 1982. 